travel together', he notes, and goes on to record 'in narrow lanes we were often much inconvenienced by these unceremonious travellers'.

At Tincroft mine he notes that the engine was on 'Hornblower's principle'. This is an interesting footnote to history, for Hornblower was trying to break the monopoly which patent rights had given to Boulton and Watt. The latter were eventually forced to fight a lawsuit to retain their monopoly.

Maton, however, was a physician and his observations in this field are interesting. He gives the mining population of the country as 15000 men, women, and children. Of the miners he says:

'Most of the miners have a wretched, emaciated appearance, for they suffer from dampness, impurity of air, heat, and numerous other causes, though in Cornwall they are subjected to the fatal effects of choak damps less than in any other mining countries. From enquiries we made amongst these miners, the most general inconvenience experienced with regard to their bodily health is a tightness and constant uneasiness of the thorax.'

The significant fact here, apart from the symptoms described, is that he made enquiries, surely one of the earliest excursions in the field of industrial disease in this country.

In Hayle he visited the copper smelting houses, and he writes:

'Nothing can be more shocking than the appearance which the workmen in the smelting houses exhibit. So dreadfully deleterious are the fumes of arsenic constantly impregnating the air of these places and so profuse is the perspiration occasioned by the heat of the furnaces that those who have been employed at them but a few months become most emaciated figures and in the course of a few years are generally laid in their graves. Some of the poor wretches who were ladling the liquid metal from the furnaces to the moulds looked more like walking corpses than living human beings. How melancholy a circumstance to reflect upon yet to how few does it occur, that in preparing the materials of those numerous utensils which we are taught to consider indispensable in our kitchens, several of our fellow creatures are daily deprived of the greatest blessing of life, and too seldom obtain relief but in losing life itself.'

No doubt modern industrial physicians will disagree with his diagnosis but this was 1794 and his observations must have been novel for those days. There is probably little copper worth getting in Cornwall now, but a good deal of tin. As the earth's tin reserves shrink, mining must eventually come back to the county. Only Geevor and South Crofty now work, though there is talk of opening up Levant again and prospecting elsewhere. One of the limiting factors in reopening the Cornish mining industry could be that the Cornishman, after more than 1000 years of disembowelling his own county, may be losing his taste for mining. Foreigners are now employed in those mines which still continue to function, so if you shout down a hole in Cornwall now or in the future the answer may well come back in Italian!

\section{References}

Abbott, H. A. (1920). Home Office. Report on the circumstances attending the breaking of a man-engine which occurred at the Levant Mine, Pendeen, in the County of Cornwall on the 20th October, 1919. (Cmd. 557.) H.M.S.O., London.

Maton, W. G. (1797). Observations relative chiefly to the Natural History, Picturesque Scenery, and Antiquities of the Western Counties of England made in the Years 1794 and 1796, illustrated by a Mineralogical Map and 16 Views in Aquatinta by Alken, by William George Maton, M.A., Fellow of the Linnaean Society. (2 vols.), J. Easton, Salisbury.

Received for publication July 23, 1969.

\title{
Erythrocytes of uranium miners: the red blood picture
}

\author{
Z. VICH and J. KR̈IKLAVA \\ Health Institute of Uranium Industry, Príbram, Czechoslovakia
}

Vích, Z., and Křiklava, J. (1970). Brit. J. industr. Med., 27, 83-85. Erythrocytes of uranium miners: the red blood picture. Haemoglobin concentrations, erythrocyte counts, haematocrit values, and mean corpuscular volumes, haemoglobin, and haemoglobin concentrations were determined on a group of miners in a uranium mine and in unexposed persons. There were small, statistically significant differences of mean values from those of controls, but the mean values remained well within normal limits. There was no evident damage to red blood cell formation. 
White cell counts are used as indices of the effects of radiation on blood-producing organs and on the whole organism. Although a somewhat coarse one, they still constitute an easily available preventive measure.

Our aim was to see whether there were any alterations in the measurements associated with the red blood cells in uranium miners who form a special group of persons exposed to chronic radiation in their work. These were studied especially because differing opinions prevailed as to whether there were any alterations which could be used to indicate exposure to radiation.

\section{Materials and methods}

Haemoglobin and the red cell count were measured in 4021 persons examined during one year, namely, 3642 healthy uranium miners from the region of Pryibram, working underground, who were examined periodically to monitor exposure, and 379 healthy men asking for employment in the mines. In a smaller group, 1717 miners and 249 non-miners, haematocrit values, mean corpuscular volumes, mean corpuscular haemoglobin, and mean corpuscular haemoglobin concentrations were obtained.

Haemoglobin was determined as cyanmethaemoglobin by photocolorimetry. The erythrocytes were counted in a Bürker chamber after blood dilution with Hayem solution. The haematocrit value was determined in Wintrobe's haematocrit tubes. The calculations of red cell parameters were made according to standard formulae (Netoušek, 1962).

\section{Results}

The miners were treated as four groups according to the number of years of exposure.

TABLE 1

haemoglobin Concentrations, ERythrocyte Counts and Haematocrit Values in Controls AND URANIUM MINERS Means \pm SDs

\begin{tabular}{|c|c|c|c|}
\hline $\begin{array}{l}\text { Working } \\
\text { exposure } \\
\text { of groups }\end{array}$ & $\stackrel{H b}{(g / 100 ~ m l)}$ & $\begin{array}{c}\text { Erythrocyte } \\
\text { counts } \\
\text { (millions) }\end{array}$ & $\begin{array}{c}\text { Haematocrit } \\
(\%)\end{array}$ \\
\hline $\begin{array}{l}\text { Not working } \\
\text { in mines }\end{array}$ & $15 \cdot 0 \pm 0.8$ & $4.58 \pm 0.25$ & $44 \cdot 8 \pm 2 \cdot 7$ \\
\hline $\begin{array}{c}\text { Uranium miners } \\
<5 \text { years } \\
6-10 \text { years } \\
11-15 \text { years } \\
16-20 \text { years }\end{array}$ & $\begin{array}{l}15.0 \pm 0.8 \\
14.8 \pm 0.8^{2} \\
14.6 \pm 0.9^{2} \\
14.7 \pm 0.9^{2}\end{array}$ & $\begin{array}{l}4.64 \pm 0.24^{2} \\
4.61 \pm 0.26^{1} \\
4.65 \pm 0.26^{2} \\
4.56 \pm 0.28\end{array}$ & $\begin{array}{l}45 \cdot 3 \pm 2 \cdot 8 \\
44 \cdot 9 \pm 2 \cdot 9 \\
45 \cdot 1 \pm 2 \cdot 9 \\
45 \cdot 1 \pm 3 \cdot 2\end{array}$ \\
\hline
\end{tabular}

Where mean is different from mean of controls:

${ }^{1} P<0.05$

${ }^{2} \mathrm{P}<0.001$
TABLE 2

Mean Corpuscular Volumes, Haemoglobin and HaEmoglobin Concentrations Means \pm SDs

\begin{tabular}{|c|c|c|c|}
\hline $\begin{array}{l}\text { Working } \\
\text { exposure } \\
\text { of groups }\end{array}$ & $\begin{array}{c}M C V \\
\left(\mu^{3}\right)\end{array}$ & $\begin{array}{c}M C H \\
(p g)\end{array}$ & $\begin{array}{c}M C H C \\
(\%)\end{array}$ \\
\hline $\begin{array}{l}\text { Not working } \\
\text { in mines }\end{array}$ & $97 \cdot 2 \pm 3 \cdot 2$ & $32 \cdot 3 \pm 0.9$ & $33.4 \pm 1 \cdot 2$ \\
\hline $\begin{array}{c}\text { Uranium miners } \\
<5 \text { years } \\
6-10 \text { years } \\
11-15 \text { years } \\
16-20 \text { years }\end{array}$ & $\begin{array}{l}97 \cdot 2 \pm 2 \cdot 9 \\
97 \cdot 8 \pm 2 \cdot 7^{2} \\
97 \cdot 5 \pm 2 \cdot 8 \\
98 \cdot 0 \pm 2 \cdot 8^{1}\end{array}$ & $\begin{array}{l}32.3 \pm 0.8 \\
32 \cdot 3 \pm 1 \cdot 0 \\
32 \cdot 1 \pm 0.9^{2} \\
32.4 \pm 1.0\end{array}$ & $\begin{array}{l}33 \cdot 2 \pm 1 \cdot 2^{1} \\
33 \cdot 0 \pm 1 \cdot 1^{3} \\
33 \cdot 1 \pm 1 \cdot 3^{2} \\
33 \cdot 1 \pm 1 \cdot 2^{1}\end{array}$ \\
\hline
\end{tabular}

Where mean is different from the mean of controls:

${ }^{1} \mathrm{P}<0.05$

${ }^{2} \mathbf{P}<0.01$

${ }^{3} \mathbf{P}<0.001$

Table 1 shows the haemoglobin concentrations, erythrocyte counts, and haematocrit values. Table 2 shows the mean corpuscular volumes (MCV), mean corpuscular haemoglobins (MCH), and mean corpuscular haemoglobin concentrations (MCHC). The statistical significances of the differences from control values are shown. The values for the controls had the characteristics of the normal healthy male population of Czechoslovakia (Krriklava and Vích, 1969).

\section{Discussion}

The influence of chronic radiation on uranium miners is frequently discussed. It is known that these workers have an increased incidence of cancer of the lung, but there is in them no unambiguous set of clinical symptoms representing radiation damage (Ševc, 1967). It is not even known whether there are any aberrations within the framework of a generally good state of health.

The deviations from normal in the red blood cell picture found here were not unambiguous. Similar small and variable changes have also been found by others investigating this problem (Borovanský, 1933; Petráček, 1953; Henn, 1954; Henn and Leibetseder, 1955; Pelnáŕ, Kuřetová, Nováková, Roubal, and Šplíchal, 1959; Polák and Kerǔicha, 1962; Dominas-Kuczkowska, BogusławskaJaworska, and Dobryszycka, 1963; Bakstein, 1966; Křiklava and Vích, 1968; Vích, Křiklava, and Beran, 1968).

The differences from the controls of the mean values were always very small, but several were statistically significant. The decrease in haemoglobin content and the tendency to macrocytosis 
were presumably caused by the radiation to which the miners were exposed. However, while the mean values were slightly altered, they always remained well within the normal range, so that values on individual miners could not be used as an index of exposure.

\section{References}

Bakstein, J. (1966). State of Health of Uranium Miners established on the Basis of Periodic Preventive Examinations (In Czech). Dissertation, Přibram.

Borovanský, M. (1933). Final report about the sanitary state of miners from Jáchymov in 1933 (In Czech). Unpublished manuscript. Cited by Petrácek (1953).

Dominas-Kuczkowska, H., Bogusławska-Jaworska, J., and Dobryszycka, W. (1963). Influence of decay products of the uraniumradium sequence on workers from uranium mines (In Polish). Pol. Tyg. Lek., 18, 561-563.

Henn, O. (1954). Zur Frage der Toleranzdosis des menschlichen Organismus bei Inhalation von Radium-Emanation. Strahlentherapie, 94, 441-454.
_ and Leibetseder, F. (1955). Schädigung der Hämopoese beim Menschen durch langdauernde Einwirkung kleinster Dosen Radiumemanation. Ibid., 97, 435-443.

Krriklava, J,. and Vích, Z. (1968). Haemogram in employees of the uranium mines in the Príbram area (In Czech). Cas. Lék. Ces., 107, 1367-1372.

- and - (1969). Problems of the normal values of the blood picture in men (In Czech). Prakt. Lék., 49, 266-268.

Netousek, M. (1962). Clinical Haematology (In Czech). St. Zdrav. Nakl., Prague.

Pelnáŕ, P., Kuřetová, V., Nováková, O., Roubal, F., and Šplíchal, A. (1959). The state of health of workers in the assortment section for uranium ore (In Czech). Proceedings of the 6th Nat. Congr. Occup. Med. in Bilá, Prague, pp. 124-134.

Petrácek, E. (1953). Radiation and professional lung cancer (In Czech). In Primary Lung Cancer. Review of Reports. Pp. 25-32. St. Zdrav. Nakl., Prague.

Polák, H., and Řerricha, V. (1962). The blood picture in workers of the Jáchymov mines (In Czech). Review of Research Reports. No. 1. Pp. 15-22. Příbram.

Sevc, J. (1967). Sanitary and hygienic problems in the uranium industry (In Czech). In Working Security and Hygiene. Collection of Lectures. Pp. 185-196. Přibram.

Vích, Z., Křiklava, J., and Beran, M. (1968). The results of some haematological tests in uranium miners. Proc. Sth Int. congr. prev. Med., Rome, p. 186.

Received for publication June 20, 1969

\section{The October (1969) Issue}

Theory and practice of colour vision testing: A review Part 2 R. LAKowsKI

Constitutional differences between men recruited for driving and non-driving occupations $R$. M. OLIVER

A study of the mortality of workers in an asbestos factory M.L. NewHOUSE

Validation of death certificates in asbestos workers $M$. L. NewhOUSE and J. C. WAGNER

A population study in cotton ginnery workers in the Sudan Mustafa Khogali

Effects in man and rabbits of inhalation of cotton dust or extracts and purified endotoxins G. CAVAGNA, V. Fò̀, and E. C. VIGLIANI

Exposure of spray operators to paraquat A. A. B. SwAN

Quantitative determination in urine of hippuric acid and $m$ - or $p$-methylhippuric acid, metabolites of toluene and $m$ - or $p$-xylene M. Ogata, K. TOMOKUNI, and Y. TAKATSUKA

Effects of carbon disulphide on the liver of rats E. J. BOND, W. H. BUTLER, F. DE MATTEIS, and J. M. BARNeS

Dieldrin poisoning in dogs: relation to obesity and treatment William T. KeANe, Mitchell R. Zavon, and SAMuel H. WitheruP

Book reviews

Current awareness

Index

A number of copies are still available and may be obtained from the Publishing Manager, British Medical Association, Tavistock Square, London W.C.1, price 22s. $6 d$. 